\title{
SCIENCE.-Supplement.
}

FRIDAY, JANUARY 15, 1886.

\section{THE EIGHT-HOUR DAY.}

CoNSIDERING the interest which is everywhere awakened in face of the coming determined agitation for an eight-hour day, the pamphlet by H. W. Fabian, on 'Der gesetzliche achtstundige normal-arbeitstag' (Social science publishing company, New York), is quite opportune. It constitutes the first number of a cheap series devoted to economic and social questions. Apart from its purpose of concentrating certain facts concerning the development of legislation on this subject, it is perhaps noticeable as indicating the diffusion of the writing and theories of Marx. His philosophy is accepted as laying the basis for state action in economic matters. It is a debated question, even among the labor-leaders, as to whether they will be able to carry into successful operation their plan for the general adoption of the eight-hour day on May 1, 1886. This is the date determined upon by the federation of labor unions of the United States and Canada. Such a thorough-going undertaking has immense diffculties before it, if it is managed simply as an economic movement. Many trades are not thoroughly organized; large numbers of workmen have no savings ; and of course, if a general strike in all industries be resorted to, there could be little hope of mutual aid. Again : the system of piece-work is a standing obstacle. This is seen in the case of cigar-makers who work in tenementhouses. Mr. Fabian, therefore, urges the necessity of combined political action : economic forces alone are not sufficient. Those who are perplexed and possibly exasperated by this movement should make themselves familiar with the history of the labor-day. Even so conservative an investigator as Thorold Rogers has shown, that, in battling for the eight-hour day, the workman is only claiming his inheritance which he possessed less than five centuries ago. The demand is not a radical one; and no question was ever more temperately discussed than this at the recent Washington labor congress. For more than a quarter of a century the working-day in Australia has been of but eight hours; and last April the anniversary of its introduction was celebrated by artisans, manufacturers, and government officials. All these united in a declaration of its success.
E. $\mathbf{Y}$.

\section{SHELL-FISH IN CONNECTICUT.}

THE ' Fifth report of the shell-fish commissioners of the state of Connecticut,' for 1885, shows that the total area of oyster-grounds, for which application has been made to the commission (or their predecessors in certain places, the town committees) exceeds a hundred and twenty-four thousand acres. This, it is understood, excludes all natural beds or property owned by towns for the common benefit. Of the total, nearly eighty thousand acres have already been granted, of which sixteen thousand two hundred are under cultivation. Such portions of the remainder as are held for speculation, and not cultivated, revert to the state after five years, at the order of court, on a proper showing. In 1885 there were four hundred and twenty-three tax-paying cultivators, and the nominal price fixed on the grounds has yielded the state over fifty thousand dollars. The commissioners recommend the repeal of that section of the law which excludes non-residents from its privileges; as the local oyster-growers have had full opportunity for securing such lands as they could use, and, ignorantly or intentionally, nonresidents have secured ownership through a merely fictitious compliance with the letter of the law. Of taxes levied, all but fifty-five dollars have been collected ; the tax produced nearly eight thousand dollars the present year, and nearly eighteen thousand dollars during the entire three years. Much available ground still remains open to designation.

The experience of cultivators shows, that with proper dredging vigilantly kept up, and a suitable state supervision of the natural beds, the starfish may be kept under so as to do but little damage. A new pest was reported in the worm Sabellaria vulgaris Verrill, which builds interlocking sandtubes with great rapidity, which, when numerous enough, smother the oysters on which they rest. One bed containing seventy-eight thousand bushels was nearly destroyed in this way; but it seems that such a result is very rare, as no further serious damage from this cause has been reported, and it is possible the loss in question was overestimated.

The oyster-fleet of 1885 comprised 49 steamers, with a capacity of 50,525 bushels.

Mr. Bogart, the efficient engineer of the comission, reports on his part of the work, which is chiefly occupied with the survey of the state oyster-grounds, and the determination of bound- 
aries of private claims, - often a difficult task, owing to their distance from shore.

The laws relating to shell-fish, passed since the date of the last report, are appended. The only one of general importance makes the rights to oyster-grounds personal estate, and not realty, in settling property of deceased owners.

The example of the state of Connecticut, in full accordance with the business sagacity which characterizes her citizens, might well be followed by other states even more deeply interested in oysterculture. The natural beds of Maryland and Virginia are being rapidly destroyed for commercial purposes, and only a prompt attention to the subject can secure their rescue from impending destruction.

\section{DATE OF VINTAGE.}

M. ANGot contributes a long discussion of the date of vintage in France to the annals of the

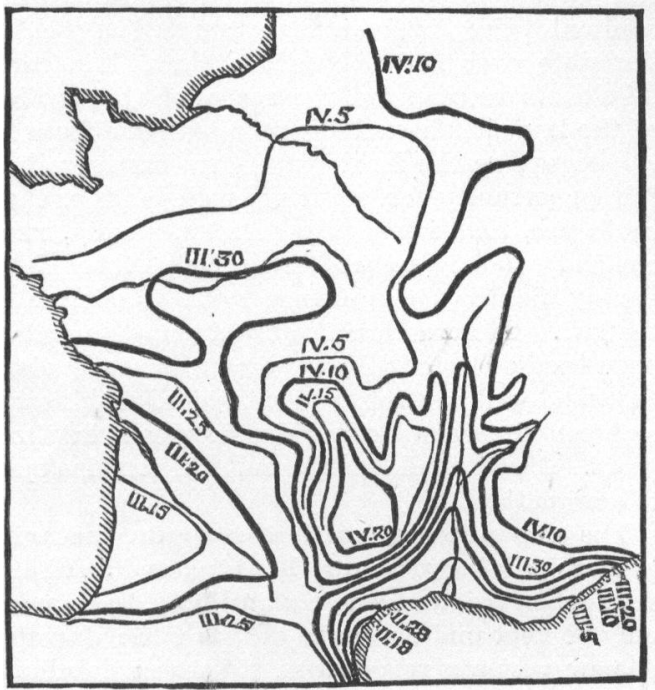

Fig. 1.

Bureau central météorologique for 1883 , issued with date of 1885. His data for some stations reach back to the fourteenth century, and, for a good number, back well into the eighteenth century. His conclusions may be briefly summarized as follows: $1^{\circ}$. The date of vintage varies greatly from year to year, and may in a single country differ by more than seventy days in different years. $2^{\circ}$. The date of maturity depends chiefly on the vines having received a certain quantity of heat, well determined for each species. $3^{\circ}$. Slight variations in the mean date of vintage are found ; but these variations are unlike in neighboring regions, and they show no persistent deterioration of climate. $4^{\circ}$. No relation is found between the date of vintage and the sun-spot cycle. $5^{\circ}$. Abundant vintages occur in rather warm years, with nearly normal rainfall : they are less dependent on a concurrence of favorable conditions than on the absence of frosts, hail, diseases of the vines, etc. $6^{\circ}$. Years of good wine have a notable high temperature from June to September, and generally a slightly deficient rainfall. $7^{\circ}$. Years of poor wine are cool in the summer, with rain a little above the normal. Since 1880, detailed observations have been made on the vintage in France, and in future it will be regularly discussed.

The accompanying cuts are reduced from Angot's plates. Fig. 1 shows the budding of the vine in spring-time, as determined by the arrival of the mean diurnal temperature of $9^{\circ} \mathrm{C} .\left(48^{\circ} \mathrm{F}\right.$.), which is provisionally accepted as the time of the beginning of its vegetation. The position of this isotherm for every ten days of February, March,

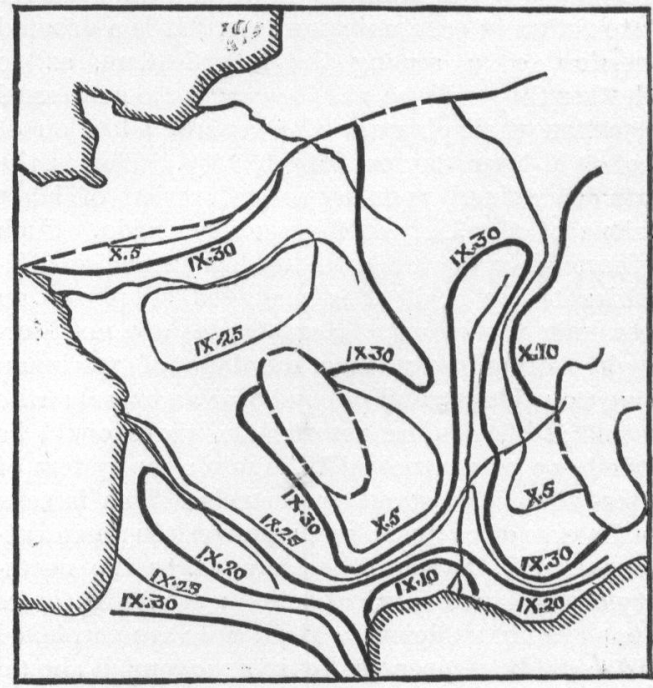

Fia. 2.

and April, is given by heavy lines; for some intermediate dates, by finer lines. The epoch of vintage in the autumn is similarly expressed in Fig. 2.

The same author has also attacked the distribution of heat on the earth as directly furnished by the sun, giving the basis of what Hann calls the solar climate. Meech is most frequently quoted on this question, and Ferrel has lately discussed it ; Angot adds the consideration of various coefficients of atmospheric transparence, and thus makes a step from the theoretical towards the actual. For example : according to Meech, the 